\title{
Correction to: Loteprednol Etabonate (Submicron) Ophthalmic Gel 0.38\%: A Review in Post-Operative Infammation and Pain Following Ocular Surgery
}

\author{
Connie Kang ${ }^{1} \cdot$ Susan J. Keam ${ }^{1} \cdot$ Matt Shirley $^{1} \cdot$ Yahiya Y. Syed $^{1}$
}

Published online: 14 December 2020

(c) The Author(s) 2020

\section{Correction to: \\ Clinical Drug Investigation (2020) 40:387-394 \\ https://doi.org/10.1007/s40261-020-00899-2}

The article Loteprednol Etabonate (Submicron) Ophthalmic Gel 0.38\%: A Review in Post-Operative Inflammation and Pain Following Ocular Surgery, written by Connie Kang, Susan J. Keam, Matt Shirley and Yahiya Y. Syed, was originally published Online First without Open Access. After publication in volume 40, issue 4, pages 387-394 Bausch Health US, LLC requested that the article be Open Choice and to make the article an Open Access publication. Post publication open access was funded by Bausch Health US, LLC. This article is licensed under a Creative Commons Attribution-Noncommercial 4.0 International License, which permits any non-commercial use, sharing, adaptation, distribution and reproduction in any medium or format, as long as you give appropriate credit to the original author(s) and the source, provide a link to the Creative Commons licence, and indicate if changes were made. The images or other third party material in this article are included in the article's Creative Commons licence, unless indicated otherwise in a credit line to the material. If material is not included in the article's Creative Commons licence and your intended use is not permitted by statutory regulation or exceeds the permitted use, you will need to obtain permission directly from the copyright holder. To view a copy of this licence, visit https ://creativecommons.org/licenses/by-nc/4.0/.

The original article has been corrected.

The original article can be found online at https://doi.org/10.1007/ s40261-020-00899-2.

Connie Kang

demail@springer.com

1 Springer Nature, Mairangi Bay, Private Bag 65901, Auckland 0754, New Zealand
Open Access This article is licensed under a Creative Commons Attribution-NonCommercial 4.0 International License, which permits any non-commercial use, sharing, adaptation, distribution and reproduction in any medium or format, as long as you give appropriate credit to the original author(s) and the source, provide a link to the Creative Commons licence, and indicate if changes were made. The images or other third party material in this article are included in the article's Creative Commons licence, unless indicated otherwise in a credit line to the material. If material is not included in the article's Creative Commons licence and your intended use is not permitted by statutory regulation or exceeds the permitted use, you will need to obtain permission directly from the copyright holder. To view a copy of this licence, visit http://creativecommons.org/licenses/by-nc/4.0/. 